Running head: AN ANALYSIS OF COLLEGE CHOICE INFORMATION

\title{
An Analysis of College Choice Information Provided on Graduate Program Websites: Implications for Improving Applicant Diversity in Educational Measurement
}

\author{
Joseph A. Rios ${ }^{\mathrm{a}}$, Jennifer Randall ${ }^{\mathrm{b}}$, Marina Donnelly ${ }^{\mathrm{b}}$ \\ anniversity of Minnesota \\ bUniversity of Massachusetts Amherst
}

\begin{abstract}
Author Note
The authors would like to thank Lauren R. Erickson from the University of Massachusetts Amherst for her assistance with coding.

Author contribution statement:

The first author conceived of the presented idea. All authors were involved in data collection with the fourth author conducting the search, authors two and three selecting studies and coding variables, and the first author supervising all work. The first three authors conducted data analyses and interpreted the findings. Although the majority of writing was done by the first two authors, every author wrote different aspects of the manuscript. Authors three and four provided feedback on the draft and the first and second authors conducted critical revisions of the article throughout the review process. Final approval of the version to be published was made by all authors.
\end{abstract}

Correspondence concerning this article should be addressed to Joseph Rios, University of Minnesota, 56 East River Road, Education Sciences Building 164, Minneapolis, MN 55455

Email: jrios@umn.edu

This is the accepted version of the following article:

Rios, J. A., Randall, J., \& Donnelly, M. (2019). An Analysis of College Choice Information Provided on Graduate Program Websites: Implications for Improving Applicant Diversity in Educational Measurement. Educational Measurement: Issues and Practice. Advanced online publication. doi: 10.1111/emip.12284

It has been published in final form at https://onlinelibrary.wiley.com/journal/17453992. This article may be used for non-commercial purposes in accordance with the Wiley Self-Archiving Policy [http://www.wileyauthors.com/self-archiving]. 


\begin{abstract}
There has long been a concern about the lack of representation of ethnic minorities in the field of educational measurement. As previous research has shown that graduate programs primarily rely on their websites for recruiting efforts, the objective of this study was to conduct a content analysis of all U.S. educational measurement program websites to evaluate the availability of college choice information found to be useful for underrepresented ethnic minority applicants. In terms of program climate, results revealed that less than $10 \%$ of programs directly encouraged ethnic minorities to apply or included an anti-discrimination statement in regards to application review on their websites. Moreover, only a few program websites indicated the availability of flexible programming - previously found to be important for underrepresented ethnic minority students - such as part-time options (16\%), evening courses (10\%), and online course/program availability ( $8 \%$ ). Recommendations for how measurement programs can improve their websites to include desirable college choice information for underrepresented ethnic minority applicants is discussed.
\end{abstract}

Keywords: educational measurement, psychometrics, diversity, underrepresented ethnic minorities, graduate admissions 


\section{An Analysis of College Choice Information Provided on Graduate Program Websites: Implications for Improving Applicant Diversity in Educational Measurement}

Within the United States, a massive shift in cultural and social norms is occurring as the demographics of the nation continue to change and form an increasingly ethnically and linguistically diverse population (Kent, 2015). This demographic shift is particularly reflected in the K-16 student population. Since 1968, the percentage of White students in K-12 has decreased by $30 \%$, while within the same timeframe, Latino and Asian student representation has increased by roughly $500 \%$ and $900 \%$, respectively (NCES, 2016). This trend only looks to continue as it is projected that by $2024,55 \%$ of all students will be non-White (Kena et al., 2015). The ethnic shift in the student population has greatly influenced the linguistic diversity seen in the U.S. public school system. Currently, there are 4.6 million students (approximately $10 \%$ of the student population) that are classified as English language learners (ELLs). Of these individuals, 77\% are native Spanish speakers (NCES, 2017). However, increased linguistic and ethnic diversity is not isolated to the K-12 population. The number of Black and Latino students (many of whom are English language learners) taking college admissions tests has generally increased over time and the number enrolling in higher education institutions has more than doubled over the last 20 years (e.g., Aud, Fox, \& KewalRamani, 2010; Musu-Gillette et al., 2016).

The observed and anticipated demographic shift in the U.S. student population has implications for the educational assessment field. Specifically, the growth in diversity raises the concern of increasingly needing to take sociocultural factors into consideration as assessment is impacted by cultural and social norms. Such norms influence decisions about how learning will be assessed, individuals' willingness to participate in assessment practices, and how responses to these practices are evaluated, interpreted, and used (Harris \& Brown, 2016; Hattie, 2016). Failing to consider sociocultural issues may lead to inequities in the assessment process and incorrect 
expectations about the ways in which assessment can contribute to fair education reform (Ercikan \& Solano-Flores, 2016).

One way to address the increasing demands of a diverse student population and the changing cultural and social norms occurring in the U.S. is to establish a workforce of educational assessment specialists that reflects the multifaceted cultures and societal characteristics (e.g., parental socioeconomic class, worldviews, values, customs, and communication styles) of the country. Indeed, the benefits of a diverse workforce, in general, are well-documented. Pettigrew and Tropp (2006) found via a meta-analysis that intergroup contact reduced prejudice among individuals from diverse backgrounds. Moreover, these benefits from contact with minoritized groups extended or generalized to other minoritized groups.

Furthermore, and perhaps most importantly, a diverse workforce promotes greater cultural awareness (Christ et al. 2014) and provides greater awareness into the best ways to support underserved populations (Reskin, 1998). Despite the inherent benefits and increasing calls for a more diverse assessment community (Sireci, 2000), the field has historically (and currently) been unable to recruit domestic born Blacks, Latinos, and Native Americans (hereon referred to as underrepresented ethnic minorities ${ }^{1}$ ), who mirror the communities that we serve.

\footnotetext{
${ }^{1}$ In this paper, we define underrepresented ethnic minorities as domestic born Blacks, Latinos, and Native Americans. These subgroups have been historically underrepresented in the U.S. higher education system when compared to White and Asian Americans (Ryan \& Bauman, 2016). Though, we acknowledge that Asian Americans are a diverse group representing numerous ethnicities and that Asian American subgroups have been found to differ in higher education attainment (e.g., East and Southeast Asian Americans; National Center for Education Statistics, 2019). Unfortunately, this diversity may go unseen by demographic information collected within the educational measurement field as researchers have classified Asians into a single homogenous group failing to consider both an individual's nationality and ethnicity (prior research suggests that this may be a general problem in educational research; Tran \& Birman, 2010). For the sake of this paper, we focus on domestic born Blacks, Latinos, and Native Americans, but recognize that there may be a number of Asian American subgroups (e.g., Hmong, Laos, and Vietnamese Americans) that are also underrepresented in our field. Regardless, the findings and recommendations from this paper may have implications for improving recruitment of all ethnic minority groups that lack representation in the educational measurement field.
} 
Patellis, Kolen, and Parshall (1997) explored the ethnic composition of students in educational measurement graduate programs $(n=60)$ and found that only $5 \%$ and $2 \%$ of doctoral students were Black and Latino, respectively. More than a decade later, based on data collected from the National Science Foundation's Survey of Earned Doctorates between 2007 and 2016, the annual percentage of Black and Latino doctoral recipients in the fields of educational measurement and quantitative methodology was as low as $6 \%$ and $1 \%$, respectively, for all domestic (non-visa) graduates (Table 1). In 2010, Packman, Camara, and Huff (2010) surveyed 142 members of the National Council on Measurement in Education (NCME), the world's largest professional measurement organization, and found that the two largest ethnic groups were Whites and Asians (accounting for approximately $91 \%$ of all members), suggesting that the low underrepresented ethnic minority representation in graduate programs is also reflected in the general measurement profession. Currently (as of May 2018), NCME boasts 1,392 members and of that membership, only 87 (6.25\%) identify as Black/African American, 70 (5.03\%) identify as Hispanic (many of whom were educated and work outside of the United States), and 16 (1.15\%) identify as American Indian/Native American. This current lack of ethnic diversity, though troubling, is not unexpected. Indeed, there has long been a concern that graduate programs are not adequately producing enough graduates to meet the growing demand for measurement specialists, and this shortage has been suggested to be partly attributed to the lack of underrepresented ethnic minority recruitment (Brennan \& Plake, 1991; Sireci, 2000).

Though there are few underrepresented ethnic minorities in educational measurement relative to other professions in the social sciences (Sireci, 2000), previous research has found that as many as $99 \%$ of educational measurement programs do not actively recruit students (i.e., the process of attracting students to apply to a given measurement program; Patellis et al., 1997). In 
a more recent 2017 study of recruitment practices by faculty members from quantitative methodology and/or educational measurement programs, Rios (2018) found that $77 \%$ of respondents reported not having an articulated recruitment plan. Instead, programs were found to rely primarily on their websites $(92 \%)$ in recruiting students prior to potential applicants showing interest in the program.

Indeed other similar fields have identified websites as the most realistic and effective method - due in large part to limited resources of time and money - for the recruitment of ethnically diverse applicants and consistently analyze website content to evaluate their use in underrepresented ethnic minority recruitment (Bidell, Ragen, Broach, \& Carrillo, 2007; Smith et al., 2016). For example, Smith et al. (2013) report that school psychology programs rely primarily on their programs' websites to attract/recruit racially/ethnically/linguistically diverse students. In addition, Rogers and Molina (2006) identified eleven school psychology programs considered exemplary with respect to efforts to attract and retain minority students of color (note: programs needed to have $20 \%$ minority student of color enrollment minimally). The authors noted that with respect to students of color "Departments and programs that had online Web sites describing and advertising their graduate training were enthusiastic in portraying their Web sites as their most important recruitment tool" (p.147). The utilization of websites is important as recent research has found that $80.9 \%$ of applicants to graduate programs use program websites as their number one source for learning about college choice information (i.e., program climate, fit; Rios, Fishtein, \& Burkander, 2018). It is important to note, however, that the type of information that a program shares on its website can help to attract or potentially detract potential applicants. Smith, Blake, Graves, Vaughan-Jensen, Pulido, and Banks (2016) found that a larger percentage of counseling and clinical programs displayed statements around their commitment to diversity 
on their websites than school psychology programs. Specifically, school psychology programs were 2.31 times less likely to have a diversity statement, 2.84 times less likely to display funding opportunities for diverse applicants, and 2.82 times less likely to contain diverse faculty interests than clinical and counseling psychology programs. This website content is juxtaposed to the differential rates of diversity across the three fields - $24 \%$ of school psychology doctoral graduates identified as non-White, whereas for clinical and counseling psychology programs, the percentage of doctoral graduates identifying as non-White was 35\% and 42\%, respectively (NSF, 2014). In Rios's 2017 survey of educational measurement program faculty, very few reported that their websites included an anti-discrimination statement in relation to applications (19\%) or described a policy of recruitment for diversity in the student body (4\%; Rios, 2018).

Given that one of the most important recruitment tools that graduate programs possess are their websites (Bidell, Turner, \& Casas, 2002; Williams, 2000), it is important to study how educational measurement graduate programs are communicating important college choice information to potential underrepresented ethnic minority applicants. Specifically, research has shown that underrepresented ethnic minority applicants may benefit from programs that: (a) indicate a respect for the work/family life balance through flexible programming options, (b) provide comprehensive information and support with respect to the application and admissions process, (c) provide detailed information about financial resources and funding opportunities, and (d) address school climate concerns around race and class (e.g., Malcom \& Dowd, 2012; Ramirez, 2013). Using research from the field of psychology as a framework to inform our inquiry, the purpose of this study was to conduct a content analysis of all U.S. educational measurement program websites to investigate the availability of college choice information found to be useful for underrepresented ethnic minority applicants. In doing so, it was assumed 
that individuals viewing program websites were familiar with the field and interested in educational measurement or a similar field, such as quantitative psychology, statistics, or a substantive educational area (e.g., school psychology). The following research questions were addressed:

1. Do measurement program websites provide:

a. Information about program structures that could/would accommodate working professionals and/or individuals with family responsibilities, specifically through flexible course (e.g., night classes) and degree (part-time and/or online study) options?

b. Detailed application information with respect to the admissions process (including desirable academic background)?

c. Information on funding and job prospect opportunities?

d. Diversity-related content critical for ethnic minorities to evaluate program climate concerns?

By addressing these research questions, we hope to provide a set of concrete low/no-cost recommendations for how measurement programs may strengthen their online recruitment efforts by improving the college choice information provided for potential underrepresented ethnic minority applicants.

\section{Method}

\section{Sample Identification}

Graduate programs $(n=120)$ in educational measurement were identified using the NCME (2019) and the American Psychological Association Division 5 (2019) lists of current measurement programs. The two lists shared $52 \%$ of programs in common; $9 \%$ of the programs 
in our sample were not found on either list, but were identified by the coder during the review

process and confirmed by the principal investigator as educational measurement programs. To be included in this study, programs had to be located within the United States (no U.S. territories were included); offer at least one graduate degree (Master's, Specialist, EdD, or PhD) in the area of educational measurement, psychometrics, quantitative methods, or related field; and offer at least one measurement course within the recommended program of study. Twenty programs were excluded from the final coding process $(n=11$ from NCME list, $n=7$ from APA Division 5 list, and $n=2$ shared by both lists) as they did not meet these criteria. The final coding sample thus consisted of 100 programs.

\section{Coding}

Upon compiling the list of educational measurement programs and recording programs' basic characteristics (e.g., minority serving institution status, institution's setting, program's department, etc.) via the Peterson's education database, the Integrated Postsecondary Education Data System (IPEDS), the Minority Serving Institution (MSI) database from the University of Pennsylvania, and ApartmentGuide.com, the variable coding process consisted of a systematic review of each program's official website. All program website variables were binary coded as present or absent. The information was only coded if it was located on the program's specific webpage (with the exception of faculty research interests that could be coded either directly on the program website or through the links to external faculty profiles on the college's/institution's domain); however, if general information (e.g., financial or application) was provided for all specializations housed within a larger unit (e.g., psychology), both information unique to the educational measurement area/concentration and generic information applicable to all students under the department (e.g., educational psychology) were coded. Programs that offered several 
degree levels (e.g., PhD and Master's) were coded in their entirety, with the exception of seven cases where, upon closer review, the degree options were so significantly different from each other (different names, core faculty, or focus) that it was deemed appropriate to list and review them separately.

Initial coding was completed by one of the authors based on frequent consensus checks with the principal investigators. To ensure rating accuracy, data for $20 \%$ of the programs were double-coded. The second coder (a doctoral student) received extensive training on the process and the variables. Although no text analysis can be free of all bias, we believe we have minimized bias through both the selection of coders and the calculation of inter-reliability statistics. Specifically, coders/principle investigators represented multiple ethnic identities and (by extension) perspectives - team members identified as Hispanic, Black, White, and Eastern European. Inter-rater reliability was established by calculating percent agreement between the two coders. Average inter-rater agreement was at $91 \%$ across both programs and variables. A consensus process was completed for all disagreements in ratings, where coders debated and agreed upon the final coding together, and the final dataset was updated with consensus ratings.

\section{Variables}

In total, 47 variables were coded that can be categorized into four main themes: (a) flexible programming options, (b) application information, (c) funding and job prospect opportunities, and (d) program climate. The variable selection process was based on the inclusion of variables identified in the literature based on published website content analyses (primarily conducted within the field of psychology; Bidell et al., 2012; Smith et al., 2016) and studies of college-choice for underrepresented ethnic minority applicants. Variable information 
(see online supplemental materials for a complete list) was collected from the program-specific website for each educational measurement program.

Flexible Programming. Research has shown that when programs provide flexibility in course (e.g., night classes) and degree (e.g., part-time and/or online study) offerings, students with family and/or work responsibilities are more likely to enroll ${ }^{2}$ (Chessman, Lester, \& Gillies, 2016). As a result, we collected information on whether graduate programs provided the opportunity for students to study: (a) online, (b) part-time, and/or (c) at night.

Application information. Although it is assumed that students have an understanding of the application process when applying to graduate programs, such an assumption may be untenable for low-income and underrepresented ethnic minority students as they have been found to navigate the college choice process with fewer resources, guidance, and knowledge than their middle- or upper-class White and Asian American peers (see Ramirez, 2011). Therefore, to examine the transparency of the application process for educational measurement graduate programs, the availability of the following information was coded: (a) a statement that encourages students to contact the program with any questions regarding the application process, (b) mathematical training expected for entering students, (c) minimum undergraduate and graduate (when the program offers degree options beyond the Master's level) Grade Point Average (GPA) prerequisite, (d) suggested Graduate Record Examination (GRE) scores for competitive applicants, (e) whether the quantitative subdomain of the GRE is emphasized during the application review, (f) acknowledgement of holistic file review (i.e., flexibility is applied

\footnotetext{
${ }^{2}$ Only $39 \%$ of graduate students in the United States enroll prior to the age of 25 (Baum \& Steele, 2017), many potential applicants may have familial responsibilities (i.e., being married and/or a parent) and/or employment obligations (e.g., Kallio, 1995).
} 
during the admissions review process for otherwise exceptional applicants who might demonstrate weaknesses in their application materials), and (g) whether the program handbook is electronically available.

Funding and job prospect opportunities. As graduate students' debt accounts for $40 \%$ of the 1.44 trillion dollars of student loans in the United States, and as 55\% of all graduate students will finance their education using loans (Board of Governors of the Federal Reserve, 2017; Snyder \& Dillow, 2015; USDOE, 2012), general cost and access to financial assistance have been suggested to be some of the most important barriers to graduate school enrollment (e.g., Ekstrom, Goertz, Pollack, \& Rock, 1991; Ramirez, 2013). Financial considerations may be of particular concern for underrepresented ethnic minority applicants as undergraduate borrowing for Latino and Black students has been found to reduce the chances of their application and enrollment into graduate school, potentially due to their resistance to accumulating additional debt (Malcom \& Dowd, 2012). Furthermore, these groups have been found to possess higher rates of undergraduate debt than their white counterparts by as much as $46 \%$ (Scott-Clayton \& $\mathrm{Li}, 2016)$. Therefore, programs sharing information about financial costs and support, as well as employment and future earning potential after graduation can better assist students in weighing the costs and benefits associated with attending graduate school (see Smith et al., 2016). To address the concern of financial costs, we coded for whether programs provided the following information: (a) a statement about expected tuition expenses, and (b) potential funding opportunities. With regard to employment opportunities, we collected evidence on whether programs included information about: (a) potential careers for graduates, (b) internship or practicum sites, (c) alumni job placements, and (d) employment rates. 
Program climate. Underrepresented ethnic minority students have reported that their college choice process is influenced by concerns of program climate in regards to race (e.g., Ramirez, 2014). This concern is heightened as ethnic minorities may fail to encounter other students and professors of similar backgrounds (National Center for Education Statistics, 2017). Although programs may be limited regarding whether their climate is perceived to be problematic, they can provide information (e.g., by highlighting the focus of multiculturalism within a typical program of study) that may be helpful for underrepresented ethnic minority applicants in assessing fit (see Smith et al., 2016). To evaluate program climate, we coded for whether graduate programs provided: (a) an anti-discrimination or equal opportunity statement regarding the admissions process, (b) a statement related to encouraging ethnic and/or general diversity among students ${ }^{3}$, (c) a requirement for mandatory courses promoting ethnic and/or general diversity, (d) faculty images, (e) faculty profiles/biographies available directly on the program website, (f) information on whether at least one faculty member has research interests related to issues of ethnic and/or general diversity, (g) student images, (h) student profiles/biographies or accomplishments, (i) availability of student contact information, and (j) a statement indicating availability of graduate student funding geared specifically towards ethnically diverse students or diverse students in general.

\section{Results}

\section{Sample Description}

\footnotetext{
3 "General Diversity" was defined as any non-specific ways of emphasizing differences among groups of individuals through the use of terms such as "multi-, inter-, and cross-culturalism" or referring to non-specific "diverse," "minority," "underrepresented," "marginalized," or "underserved" groups of individuals (excluding any statements pertaining specifically and explicitly to international, linguistic, or religious diversity, disability, gender inequality/parity/feminism/sexism, etc.). "Ethnic Diversity" was defined as ways of emphasizing domestic ethnic/racial differences among groups of individuals by referring to individual ethnic or racial categories or using terms such as "race," "ethnicity," or "racism."
} 
The 100 educational measurement programs in the sample are scattered across 84 institutions. Approximately one-fifth $(n=16)$ of the institutions contain two educational measurement programs each; for $50 \%$ of those $(n=8)$, two programs are located in separate departments. Most of the reviewed programs are located in public universities $(86 \%)$. The majority of programs (72\%) are in Colleges/Schools of Education or its variations (i.e., Education and Human Development). Most of the programs offer PhD degrees (86\%), over onehalf offer Master's degrees (64\%), and 50\% offer both Master's and PhD degrees. Very few programs still offer Doctor of Education (Ed.D.; 2\%) and Education Specialist (Ed.S.; 4\%) options in addition to either PhD only, Master's only, or both. Only $12 \%$ of the educational measurement programs are housed within minority-serving institutions (MSIs; i.e., institutions defined by executive order to serve significant undergraduate ethnic minority student populations). Of these programs, 11\% are housed by Hispanic Serving Institutions (HSI), 9\% by Asian-American/Native-American/Pacific-Islander Serving Institutions (AANAPISI), and 1\% by Historically Black Colleges and Universities ${ }^{4}$ (HBCU). Across institutions, the student ethnicity breakdown by median percentage was $65 \%$ White, $8 \%$ Latino, $6 \%$ Black, $6 \%$ Asian, 5\% nonresident alien, 4\% two or more races, and 0\% American Indian.

As seen in Figure 1, educational measurement programs $(n=100)$ are available in each region of the United States (regions were identified using the United States Census geographic groupings), with the South hosting the greatest percentage of programs (35\%) followed by the Midwest (30\%), West (21\%), and Northeast (14\%). The states with the largest representation of programs were California $(n=9)$, New York $(n=7)$, Illinois $(n=6)$, and Texas $(n=6)$. These four states represent each of the four geographic regions and together comprise $28 \%$ of all

\footnotetext{
${ }^{4}$ Note that some institutions had more than one MSI designation.
} 
educational measurement programs across the United States. A total of 13 states were not found to have a program in educational measurement (Alaska, Arkansas, Idaho, Maine, Mississippi, Montana, New Hampshire, New Mexico, North Dakota, Rhode Island, Vermont, West Virginia, and Wyoming; Figure 1). Based on designations in IPEDS, over one-half of programs are located in urban settings (53\%), while the remaining programs are in suburban (31\%), exurban (14\%), and rural (2\%) locations. At the time of this analysis, according to ApartmentGuide.com, median rent for a one-bedroom apartment across all programs was $\$ 1,093$, and varied greatly per program zip code from as low as $\$ 666$ (Illinois State University) to $\$ 2,498$ (University of Southern California). Rent tended to be the highest in the Northeast (median $=\$ 1,835)$ region of the United States followed by the West $($ median $=\$ 1,497)$, the South $($ median $=\$ 937)$, and the Midwest $($ median $=\$ 891)$ regions.

Below we provide descriptive results from our analysis, which reflect aggregated data across all educational measurement programs sampled. These data describe program characteristics and websites as it appeared to the 2018-2019 cohort of graduate program applicants. Results are presented separately by: (a) flexible programming information, (b) application information, (c) funding and job prospect opportunities, and (d) program climate.

Flexible programming. Evidence of programs considering the needs of working professionals and/or individuals with familial commitments was found to be limited, as very few stated availability of part-time study (16\%), night classes $(11 \%)$, or remote study options $(8 \%)$.

Application information. Limited information regarding field-specific qualifications for admission was noted in our analysis. Specifically, in reference to successful applicants, $28 \%$ of programs suggested average or competitive GRE scores, approximately one-third (32\%) stipulated a minimum undergraduate GPA (often linked to the institution's general graduate 
admissions requirements), and for programs that had degree options beyond Master's level, 14\% listed a minimum graduate GPA. In regards to quantitative reasoning serving as a prerequisite for graduate admissions, $2 \%$ of programs emphasized the importance of GRE quantitative scores over GRE verbal scores, and 13\% provided statements regarding required mathematics or statistics background. Only $16 \%$ of the programs described their application review process as holistic, explicitly stating that considerations or flexibility might be provided for otherwise exceptional applicants or applicants who demonstrate a great fit for the program, but have a relative weakness in some of their application materials (e.g., lower than average GRE scores). Although most of the programs provided some type of contact information, one-half (52\%) explicitly encouraged interested individuals to contact the program with questions. Finally, only $32 \%$ of the education measurement programs posted electronic versions of their program handbook on their websites.

Funding and job prospect opportunities. Though many of the reviewed programs provided web links to their institution's financial aid office, tuition costs were only mentioned by $4 \%$ of programs on their websites; however, $58 \%$ specified available funding opportunities. In terms of employment prospects, $78 \%$ of programs provided a statement about prospective roles (e.g., statistician, psychometrician, consultant, faculty) that graduates are likely to occupy upon graduation, and $64 \%$ listed examples of job placements acquired by graduates. Although graduate students often gain valuable experience that could potentially lead to full-time positions through internships, it was interesting to find that only $19 \%$ of programs listed such opportunities on their program websites. Finally, as the decision to apply to graduate school is often a financial one based on the expectation of employment upon completion of the program, it is worth noting that only $3 \%$ of the programs shared graduate employment rates. 
Program Climate. Information about faculty and students allows potential applicants to glean how much of the student or faculty body is composed of individuals who look like themselves or have similar interests. This information is provided in Figure 2. Approximately one-half of the educational measurement programs provided labeled images (photos or videos) of their faculty members (54\%) and 36\% provided faculty profiles or biographies with information beyond name and title (e.g., research interests, previous employment, educational backgrounds, awards and honors) on the program website. Of those faculty who had profiles listed either on the program website or on an external faculty directory $(n=87), 46 \%$ provided an indication that at least some of their research and professional interests related to general diversity and $48 \%$ showed similar indication for interests related to ethnic diversity. These indicators could come from a specific list of research interests, from the titles of published manuscripts or presentations, from grant titles, or from personal description listed under the faculty's profile page. With respect to providing information about former or current students, $46 \%$ of the education measurement programs listed labeled images (photos or videos) of their students, $50 \%$ provided student profiles or biographies with information beyond name and program association (e.g., research interests, career plans, accomplishments, awards, publications), and $27 \%$ listed ways to contact students with questions about the program (e.g., email address, message/email, alumni contact available through faculty). Unfortunately, very few programs directly encouraged diverse $(16 \%)$ or ethnic minority $(5 \%)$ individuals to apply, listed required courses focused on general $(8 \%)$ or ethnic $(1 \%)$ diversity, or mentioned use of anti-discrimination practices during the application review process $(8 \%)$. Furthermore, very few programs provided specific information on funding available to diverse (7\%) or ethnic minority (2\%) students (Figure 2).

\section{Discussion}


A number of interesting findings were revealed from our examination of educational measurement graduate program characteristics and websites. First, the geographic dispersion of graduate programs may be very limiting for some applicants unable to conduct a national college search. Specifically, we found that there are currently 13 states where there are no educational measurement programs and some regions of the country, such as the Northeast $(14 \%$ of total programs), where a limited number of programs currently exist. Although it may be assumed that all students have the ability to relocate for graduate school, previous research has suggested that such an assumption may be untenable, particularly for individuals that have familial responsibilities or place great importance on staying close to their home community (Ramirez, 2013; Saeed et al., 2007). Proctor and Truscott (2013) found that 70\% of black school psychologists interviewed reported that the location of the program had a major impact on their decision to attend their doctoral program - mostly due to familial responsibilities and the need to be close to family. Thus, some individuals that are unable to relocate for graduate school may be deterred from entering the field. Though this issue may be alleviated to some extent by giving students the opportunity to study remotely, such opportunities are currently limited (i.e., 92\% of programs require students to attend courses in-person).

An additional finding is that there are few programs that note flexible programming options on their websites. For example only $10 \%$ and $16 \%$ of programs offer evening courses or a part-time study option, respectively. Such a finding is troubling as the average age of U.S. graduate students is 32.4 years and students of education are some of the oldest when compared to other fields of study (over $70 \%$ of educational measurement programs sampled are housed within colleges or schools of education; Council of Graduate Schools, 2009; U.S. Department of Education, 2010). Therefore, it is conceivable that some potential applicants may have financial 
and/or familial responsibilities that would require them to maintain employment while attending graduate school (e.g., Kallio, 1995). Online programs, according to Dr. Boyce Williams - former vice president for the National Council for Accreditation of Teacher Education (NCATE) - are more conducive to applicants of color with familial responsibilities (Cooper, 2008). Manzo (1994) writes "Minorities for the most part are not inclined to take risks, to give up a house, give up a job. They've worked hard to get where they are and they don't want to risk it" (p. 13). If this is the case, previous research suggests that a lack of flexibility in course and degree offerings may limit students' ability to enroll (Chessman et al., 2016). Perhaps many programs would like doctoral students to enroll full-time so that they can attend symposia and engage in research outside of class time. However, as $64 \%$ of programs currently offer terminal master's degrees in which many students are looking to gain foundational knowledge and skills to apply in practical or non-research contexts (e.g., school districts), more programs might consider offering these students greater flexibility. Such flexibility could be beneficial in attracting individuals both with applicable experience to the educational measurement field (e.g., teaching experience and/or working in schools), and a desire to make a career transition.

In regards to providing applicants with information on the credentials of successful applicants and job prospect opportunities, we found that many educational programs' websites were lacking. By failing to provide information on competitive applicants, individuals interested in applying may be at a disadvantage, particularly when considering that some may be limited in the time and money that they can allot to their applications. For instance, by not knowing what successful GPA and GRE scores are for programs of interest, students may misallocate resources (e.g., preparing program-specific application materials, and paying for application fees) in applying to programs where they have a low probability of admissions, thus, potentially limiting 
their overall chances of enrolling in an educational measurement graduate program.

Alternatively, well-qualified students may become frustrated and simply ignore/overlook programs that fail to provide this information in favor of programs that do.

Nearly all programs did not provide information about the long-term benefits associated with enrolling in a graduate program of educational measurement. In fact, only $3 \%$ of programs shared graduate employment rates. Although enrolling in an advanced degree program has been suggested to have short-term benefits (e.g., enjoyment associated with learning), students are most concerned with long-term benefits, such as improved working conditions, enhanced lifetime earnings, and a lower probability of unemployment (Ehrenberg, 1991). Individuals must weigh these long-term benefits with the costs of engaging in graduate studies, such as the direct costs of attendance (minus any financial aid), the accumulation of additional debt, and the foregone earnings while being a graduate student (Perna, 2004). Unfortunately, only 4\% of programs explicitly noted tuition costs on their websites (though many provide web links to their institution's financial aid office), while 58\% specified available funding opportunities. Overall, these findings suggest that limited cost and employment information provided to students may make it difficult for applicants to make a rational decision in regards to whether applying and enrolling in a specific program is beneficial from an economic standpoint.

The perception of campus diversity and availability of resources for minority students is consistently reported as an important factor shaping graduate school choice among students of color (e.g., Bersola, et al., 2014; Ramirez, 2013). In regards to campus diversity, our results suggest that only a small percentage of programs are located at MSIs (12\%), ensuring that many non-White students will be underrepresented on campus. Adding to this, many applicants will be unaware of the demographics of the program before visiting, as approximately $50 \%$ of programs 
provided photos and biographies of current students and faculty. Adding to campus climate concerns, merely $16 \%$ of programs encouraged diverse applicants to apply (only $5 \%$ encouraged ethnic minorities to apply), and just $8 \%$ of programs mentioned use of anti-discrimination practices during the application review process. Despite Sireci’s (2000) appeal to provide financial support to students of color to increase diversity within the field, only $7 \%$ of programs highlighted availability of funding related to diversity and $2 \%$ of programs provided information on financial assistance specific to ethnic minority status. Taken together, it appears that programs can take steps to improving applicants' perceptions of campus climate.

\section{Recommendations for Practice}

The results from this study assume that the information shared via websites accurately reflects the policies and programs that are in place for a diverse set of applicants. Though it is possible that program websites are not up-to-date or do not accurately reflect actions within the program, our analysis is reflective of what applicants for the fall of 2018 would have seen. Beyond this limitation, these results provide important implications for practice. First, previous research suggests that programs should consider attending to the needs of students who would benefit from flexible programming options, and available accommodations should be provided on the website, when available. Based on the information we collected, the current design of educational measurement graduate programs largely assumes that students will attend graduate school full-time, in-person, and take courses in the morning or early afternoon. However, such a design limits the ability of ethnic minorities that may be older and have familial and/or work responsibilities. As noted by Sireci (2000) nearly 20 years ago, there is a need for graduate programs to consider developing distance-based degree options. This is particularly important as geographically many students may not have access to a program unless they are willing to 
relocate themselves and their families to a different state or region of the country, which may be prohibitive for some. Given the increasing presence of online programming options at most major institutions of higher education (Survey of Higher Education, 2005), measurement programs' access to the required instructional supports to develop even a small online presence is an attainable and inexpensive goal as the online delivery of content is increasingly incorporated into higher education (Oregon, McCoy, \& Carmon-Johnson, 2005). To add to this, considerable research indicates that online programming can indeed be less expensive than more traditional face-to-face models. For example, Bowen (2013) found that a hybrid/blended approach to teaching a statistics course saved between $36 \%-57 \%$ of instructional costs over small sections (40 students) and 19\% over large lecture sections. Of course, programs would need to take care to ensure that the quality of online courses matches that of their traditional counterparts, however, the technological infrastructure to enact Sireci's (2000) recommendation is available for most programs. For programs housed in departments with limited or already overextended faculty, readers should consider enlisting the services of their alumni to teach online courses (to ensure continuity/consistency of the curriculum). Given most online university courses are selfsustaining (i.e. tuition covers the cost of faculty time in whole), this option is both low-cost and relatively easy to implement. Furthermore, other virtually no-costs accommodations, such as allowing students to enroll part-time and/or take courses in the evening after the traditional work day has finished, may be beneficial in assisting working professionals to enter the field. If programs offer evening courses, part-time enrollment, or options to complete whole or part of the program remotely, that information should be emphasized on the website to ensure that working professionals recognize that their unique needs will be accommodated by the program. Such statements could appear in the Questions \& Answers section of program websites. 
Second, we maintain that there are many small ways in which educational measurement programs can illustrate their commitment to diversity via their websites. For example, one simple approach is to add a statement notifying prospective students that the program appreciates and encourages diversity (both general diversity and ethnic/racial diversity) in their student body and does not discriminate in the application review process. Such a statement can be drafted with the assistance of an institution's office of diversity and inclusion. We include a sample statement in the Appendix for consideration. Similarly, if any degree of holistic application review is employed, it should be clearly reflected on the website to potentially increase the pool of talented applicants who might be lacking in one area or another (e.g., lower than expected GPA or GRE score), but are otherwise a great fit for the program. For example, one measurement program includes the following statement on its website:

"Diversity among student backgrounds and experiences is desired (see Diversity and Inclusion Statement here). To this end, REMP faculty consider the totality of the applicants as reflected in their application materials. Your cover letter is an opportunity for you to convey to the faculty a more holistic view of your strengths and potential contributions to the program. Similarly, letters of recommendation are reviewed carefully for each applicant. There are no minimum GRE cut scores for admission to REMP. We encourage all students, particularly those from underrepresented and historically marginalized groups, to apply regardless of test scores."

Third, as funding is an important aspect in the college-choice process, we recommend faculty investigate whether the school/college or the institution as a whole offer any funding 
opportunities that are geared towards diverse students and display that information on the website along with general funding information. Posting the typical costs alongside funding opportunities is another step that will allow potential applicants to make more informed decisions when selecting a graduate program. Fourth, previous studies have found that sharing labeled images or videos of students and faculty (alumni and current) and showcasing their academic, research, and personal accomplishments, allows prospective students to get a glimpse into the program climate. Furthermore, if faculty in a program value diversity and approach their research or applied work through this lens, it should be reflected on their online profile. An abbreviated profile is provided as an example:

"Dr. X, Associate Professor, joined the faculty in September 2010. She earned her Ph.D. in Educational Measurement in 2007. Prior to her graduate studies, Dr. X taught preschool and high school social studies for several years. Her research interests primarily reflect the measurement issues and concerns she encountered as a classroom teacher which include the grading practices/philosophies of teachers, particularly differential practices as they relate to students of color, first generation students, English learners, and students with disabilities. She is especially interested in the ways in which assessments (both large-scale \& classroom-based) take into consideration, and impact, historically marginalized populations in the U.S. and abroad. Currently, she is investigating the differential impact of licensure examinations on the certification rates of prospective teachers of color; and the resulting consequences on the learning experiences of students of color." 
Finally, a brief and enthusiastic welcome statement (written quote or video) from the program director, faculty, and/or students might be a great way to draw potential applicants in to learn more about the program.

Lastly, there is a need for the measurement community as a whole to take greater interest in increasing graduate enrollment of underrepresented ethnic minorities in the field. As it currently stands, demographic information of NCME membership for full members and graduate students is not tracked and disseminated on a frequent basis. For example, in the last 20 years, there has been one publication each on the demographics of NCME membership (Packman et al., 2010) and graduate students (Patellis et al., 1997). Without such information it is difficult to gauge whether increases in diversity are being made. If increases are not being made, these surveys can act as a basis for action. For example, when Sireci and Khaliq (2002) wrote their seminal work on recruitment efforts to increase diversity in the field, the results from their survey were shared with the NCME Recruitment of Educational Measurement Specialists Committee, which were used to develop recruitment materials (e.g., a biographical document that contained NCME members' stories about how they entered the field). We argue that recreating this committee would be beneficial as it would: (a) provide concerted efforts and resources to increasing recruitment that may not be available to individual graduate programs and (b) allow for NCME membership to offer suggestions on approaches to increasing recruitment of diverse individuals into the field (see Sireci \& Khaliq, 2002).

\section{Conclusion}

In a 2005 Woodrow Wilson National Fellowship Foundation report, the authors note that "While the manner in which an individual thinks has any number of complex causes, cultural identity certainly plays a part. Academic disciplines have their own cultures- habits of thought. 
The mingling of cultural and disciplinary habits guarantees the range and fullness of intellectual discovery that earns the epithet 'cosmopolitan"” (p. 8). By improving the number of underrepresented ethnic minorities in the educational assessment field, we may be able to potentially: (a) address the continual shortage of well-trained measurement specialists in the United States, (b) increase diversity of thought to improve research (i.e., influence the problems that we choose to address, the populations that we study, and our strategies for studying them, leading to greater innovation), and (c) better consider the social and cultural norms of a rapidly changing student population to create fairer assessments. We hope that at a minimum, our findings and recommendations may generate meaningful discussions on increasing underrepresented ethnic minority recruitment. However, improving program websites is but one step towards this goal, which cannot be accomplished without added efforts to increase the visibility of the measurement profession domestically. 


\section{References}

American Psychological Association (2019). Doctoral programs: Quantitative and qualitative programs in the United States of America or Canada. Retrieved from https://www.apadivisions.org/division-5/resources/doctoral

Aud, S., Fox, M. A., \& KewalRamani, A. (2010). Status and trends in the education of racial and ethnic groups. U.S. Department of Education, National Center for Education Statistics. Washington, DC: U.S. Government Printing Office.

Baum, S., \& Steele, P. (2017). Who goes to graduate school and who succeeds? AccessLex Institute Research Paper No. 17-01. Retrieved from https://ssrn.com/abstract=2898458

Bersola, S. H., Stolzenberg, E. B., Fosnacht, K., \& Love, J. (2014). Understanding admitted doctoral students' institutional choices: Student experiences versus faculty and staff perceptions. American Journal of Education, 120, 515-543.

Bidell, M. P., Ragen, J. K., Broach, C. D., \& Carrillo, E. A. (2007). First impressions: A multicultural content analysis of professional psychology program Web sites. Training and Education in Professional Psychology, 1, 204-214.

Bidell, M.P., Turner, J.A., \& Casas, J.M. (2002). First impressions count: Ethnic/racial and lesbian/gay/bisexual content of professional psychology application materials.

Professional Psychology: Research and Practice, 33, 97-103.

Board of Governors of the Federal Reserve (2017, May 5). Consumer credit. Retrieved from https://www.federalreserve.gov/releases/g19/current/default.htm

Bowen, W., Chingos, M., Lack, K., \& Nygren, T. (2013) Online learning in higher education: Randomized trial compares hybrid learning to traditional course. Education next, 13, 5865. 
Brennan, R. L., \& Plake, B. S. (1991). Surveys of programs and employment in educational measurement. Educational Measurement: Issues and Practice, 10, 32-32.

Chessman, H., Lester, J., \& Gillies, A. (2016, April). Graduate student choice: The differences between doctoral and masters students. Presented at the annual meeting of the American Educational Research Association, Washington, D.C.

Cooper, K. (2008). The World wide web of Ed.D.s. Diverse: Issues in Higher Education, 25, 2425.

Council of Graduate Schools (2009). Data sources: Non-traditional students in graduate education. Retrieved from http://www.cgsnet.org/ckfinder/userfiles/files/DataSources_2009_12.pdf

Ehrenberg, R. G. (1991). Academic labor supply. In C. T. Clotfelter, R. G. Ehrenberg, M. Getz, \& J. J. Siegfried (Eds.), Economic challenges in higher education (pp. 143-260). Chicago: University of Chicago Press.

Ekstrom, R., Goertz, M., Pollack, J., \& Rock, D. (1991). Undergraduate debt and participation in graduate education: The relationship between educational debt and graduate school aspirations, applications, and attendance among students with a pattern of full-time, continuous postsecondary education (GRE Board Research Report No. 86-05R). Educational Testing Service, Princeton, NJ.

Finney, S. J., \& Pastor, D. A. (2012). Attracting students to the field of measurement. Educational Measurement: Issues and Practice, 31, 2-7.

Harris, L. R., \& Brown, G. T. L. (2016). The human and social experience of assessment: Valuing the person and context. In L. R. Harris and G. T. L. Brown (Eds.), Handbook of human and social conditions in assessment (pp. 1 - 30). New York, NY: Routledge. 
Hattie, J. (2016). Forward. In L. R. Harris and G. T. L. Brown (Eds.), Handbook of human and social conditions in assessment (pp. ix - xii). New York, NY: Routledge.

Kallio, R. E. (1995). Factors influencing the college choice decisions of graduate students. Research in Higher Education, 36, 109-124.

Kena, G., Hussar, W., McFarland, J., de Brey, C., Musu-Gillette, L., Wang, X., ... \& Barmer, A. (2016). The condition of education 2016 (NCES 2016-144). Washington, D.C.: National Center for Education Statistics.

Kent, L. (2015, August 10). 5 facts about America's students. Washington, D.C.: Pew Research Center. Retrieved from http://www.pewresearch.org/fact-tank/2015/08/10/5-facts-aboutamericas-students/

Malcom, L. E., \& Dowd, A. C. (2012). The impact of undergraduate debt on the graduate school enrollment of STEM baccalaureates. The Review of Higher Education, 35, 265-305.

Manzo, K. (1994). On the job education: External degree programs allow professionals to earn advanced degrees. Black Issues in Higher Education, 11, 12-15.

Musu-Gillette, L., Robinson, J., McFarland, J., KewalRamani, A., Zhang, A., and WilkinsonFlicker, S. (2016). Status and trends in the education of racial and ethnic groups 2016 (NCES 2016-007). U.S. Department of Education, National Center for Education Statistics. Washington, DC. Retrieved from http://nces.ed.gov/pubsearch

National Center for Education Statistics (2019). Indicator 27 snapshot: Attainment of a Bachelor's or higher degree for racial/ethnic subgroups. Retrieved from https://nces.ed.gov/programs/raceindicators/indicator_rfas.asp 
National Center for Education Statistics (2017). The condition of education 2017 (NCES 2017144), characteristics of postsecondary faculty. Retrieved from https://nces.ed.gov/fastfacts/display.asp?id=61

National Council on Measurement in Education (2018). Contact persons and additional information for programs in educational measurement and related areas: 2018 update. Retrieved from https://higherlogicdownload.s3.amazonaws.com/NCME/c53581e4-98824137-987b-4475f6cb502a/UploadedImages/Documents/Educational_Measurement_ Program_Descriptions_2018-10-07_.pdf

Oregon, E., McCoy, L, \& Carmon-Johnson, L. ( ). Case analysis: Exploring the application of using rich media technologies and social presence to decrease attrition in an online graduate program. Journal of Educators Online, 15(2), n2.

Packman, S., Camara, W. J., \& Huff, K. (2010). A snapshot of industry and academic professional activities, compensation, and engagement in educational measurement. Educational Measurement: Issues and Practice, 29, 15-24.

Patellis, T., Kolen, M. J., \& Parshall, C. (1997). Surveys of programs and employment in educational measurement. Educational Measurement: Issues and Practice, 16, 25-27.

Perna, L. W. (2004). Understanding the decision to enroll in graduate school: Sex and racial/ethnic group differences. The Journal of Higher Education, 75, 487-527.

Pettigrew, T. \& Tropp L (2006). A meta-analytic test of intergroup contact theory. Journal of Personality and Social Psychology, 90, 751-783.

Proctor, S. \& Truscott, S. (2013). Missing voices: African American school psychologists' perspectives on increasing professional diversity. The Urban Review, 45, 355-375. 
Ramirez, E. (2011). "No one taught me the steps": Latinos' experiences applying to graduate school. Journal of Latinos and Education, 10(3), 204-222.

Ramirez, E. (2013). Examining Latinos/as' graduate school choice process: An intersectionality perspective. Journal of Hispanic Higher Education, 12, 23-36.

Ramirez, E. (2014). “¿Qué estoy haciendo aquí? (What am I doing here?)”:

Chicanos/Latinos(as) navigating challenges and inequalities during their first year of graduate school. Equity \& Excellent in Education, 47, 167-186.

Reskin, B.F. (1998). The realities of affirmative action in employment. Washington, DC: American Sociological Association.

Rios (2018). An initial investigation of recruitment and admissions practices in educational measurement programs. Manuscript in preparation.

Rios, J. A., Fishtein, D., \& Burkander, K. (2018). Increasing diversity in graduate admissions by understanding the intersection between institutional recruiting efforts and students' application and enrollment decisions. Manuscript in preparation.

Rogers, M. \& Molina, L. (2006). Exemplary efforts in psychology to recruit and retain graduate students of color. American Psychologist, 61, 143-156.

Ryan, C. L., \& Bauman, K. (2016). Educational attainment in the United States: 2015. Washington, D.C.: United States Census Bureau.

Saeed, S., Jimenez, M., Howell, H., Karimbux, N., \& Sukotjo, C. (2008). Which factors influence students' selection of advanced graduate programs? One institutions' experience. Milieu in Dental School and Practice, 72, 688-697. 
Scott-Clayton, J., \& Li, J. (2016). Black-white disparity in student loan debt more than triples after graduation (Evidence Speaks Reports, Vol 2, \#3). Brookings Institute, Washington, D.C.

Sireci, S. G. (2000). Recruiting the next generation of measurement professionals. Educational Measurement: Issues and Practice, 19, 5-9.

Sireci, S. G., \& Khaliq, S. N. (2002). NCME members' suggestions for recruiting new measurement professionals. Educational Measurement: Issues and Practice, 21, 19-24.

Smith, L., Blake, J., \& Graves S.L. (2013). School psychology programs’ efforts to recruit culturally diverse students. Trainers' Forum, 32, 4-23.

Smith, L. V., Blake, J. J., Graves Jr, S. L., Vaughan-Jensen, J., Pulido, R., \& Banks, C. (2016). Promoting diversity through program websites: A multicultural content analysis of school psychology program websites. School Psychology Quarterly, 31, 327-339.

Snyder T. D., \& Dillow S. A. (2015). Digest of education statistics 2013 (NCES 2015011). Washington, DC: National Center for Education Statistics, Institute of Education Sciences, U.S. Department of Education.

Tran, N., \& Birman, D. (2010). Questioning the model minority: Studies of Asian American academic performance. Asian American Journal of Psychology, 1, 106-118.

U.S. Department of Education (2010). Profile of graduate and first-professional students: Trends from selected years, 1995-1996 to 2007-2008 (NCES 2011-219). Retrieved from https://nces.ed.gov/pubs2011/2011219.pdf

U.S. Department of Education (2012). Financial aid for graduate and professional degree students. Retrieved from https://studentaid.ed.gov/sa/sites/default/files/graduateprofessional-funding-info.pdf 
Williams, B. (2000). To the personalized go the prospects. Journal of College Admission, 166, $21-23$

Woodrow Wilson National Fellowship Foundation (May 2005). Diversity and the PhD: A Review of Efforts to Broaden Race and Ethnicity in U.S. Doctoral Education. Princeton, NJ: Princeton University. 
Table 1

Number of doctoral degrees awarded by year, nationality, and ethnicity

\begin{tabular}{cccccccccc}
\hline & All & Temporary & Domestic Graduates & & \\
Year & $\begin{array}{c}\text { Doctorate } \\
\text { Recipients }\end{array}$ & $\begin{array}{c}\text { Visa } \\
\text { Holders }\end{array}$ & Total & $\begin{array}{c}\text { Native } \\
\text { American }\end{array}$ & Asian & Black & Latino & White & Multiple \\
\hline 2007 & 146 & 48 & 97 & 1 & 6 & 11 & 5 & 69 & 4 \\
2008 & 139 & 33 & 100 & 3 & 8 & 9 & 7 & 70 & 3 \\
2009 & 149 & 38 & 102 & 0 & 9 & 17 & 9 & 62 & 2 \\
2010 & 134 & 34 & 94 & 0 & 6 & 8 & 1 & 76 & 2 \\
2011 & 152 & 44 & 103 & 1 & 12 & 9 & 5 & 72 & 3 \\
2012 & 128 & 28 & 99 & 1 & 15 & 13 & 6 & 60 & 2 \\
2013 & 146 & 39 & 103 & 1 & 9 & 11 & 3 & 74 & 3 \\
2014 & 129 & 27 & 97 & 1 & 4 & 12 & 5 & 71 & 2 \\
2015 & 157 & 37 & 112 & 0 & 9 & 7 & 8 & 83 & 3 \\
2016 & 142 & 44 & 96 & 0 & 10 & 10 & 9 & 59 & 7 \\
\hline
\end{tabular}

Note. Data were obtained from the National Science Foundation's Survey of Earned Doctorates.

The numbers above reflect the combined graduates for the subfields "educational evaluation and research," "educational statistics and research methods," and "educational assessment, testing, and measurement." 


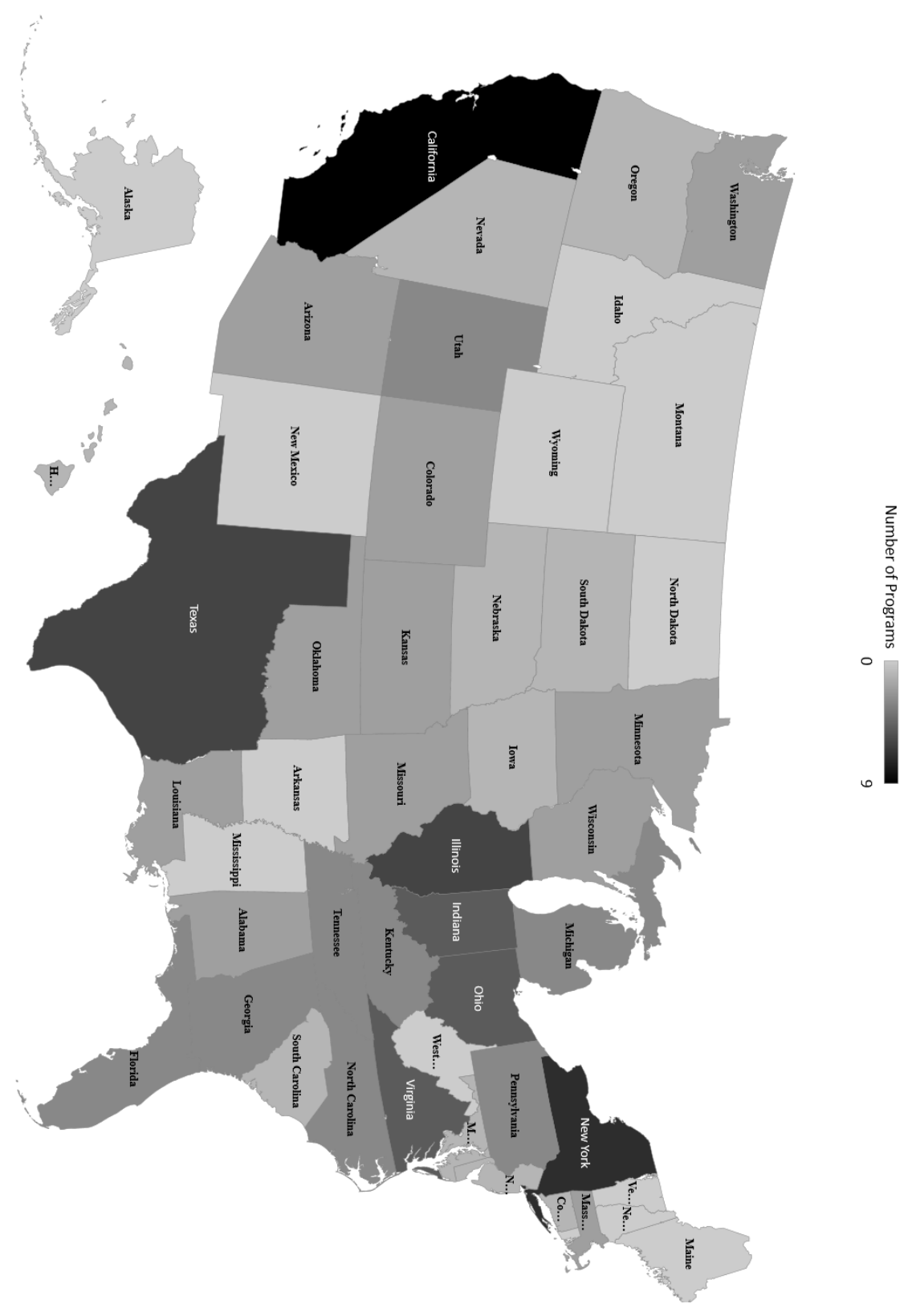

Figure 1. Number of educational measurement programs by state. 


\section{Program Climate Information}

Share faculty images

Share student profiles or accomplishments

Faculty interests focus on diversity issues

Share student images

Faculty interests focus on ethmic diversity issues

Share faculty profiles on program website

Provide former/current student contact info

Encourage diverse students to apply

Anti-discrimination statement

List required courses focused on diversity

State availability of funding for diverse students

Encourage ethmically diverse students to apply

State availability of funding for ethnically diverse students

List required courses focused on ethnic diversity

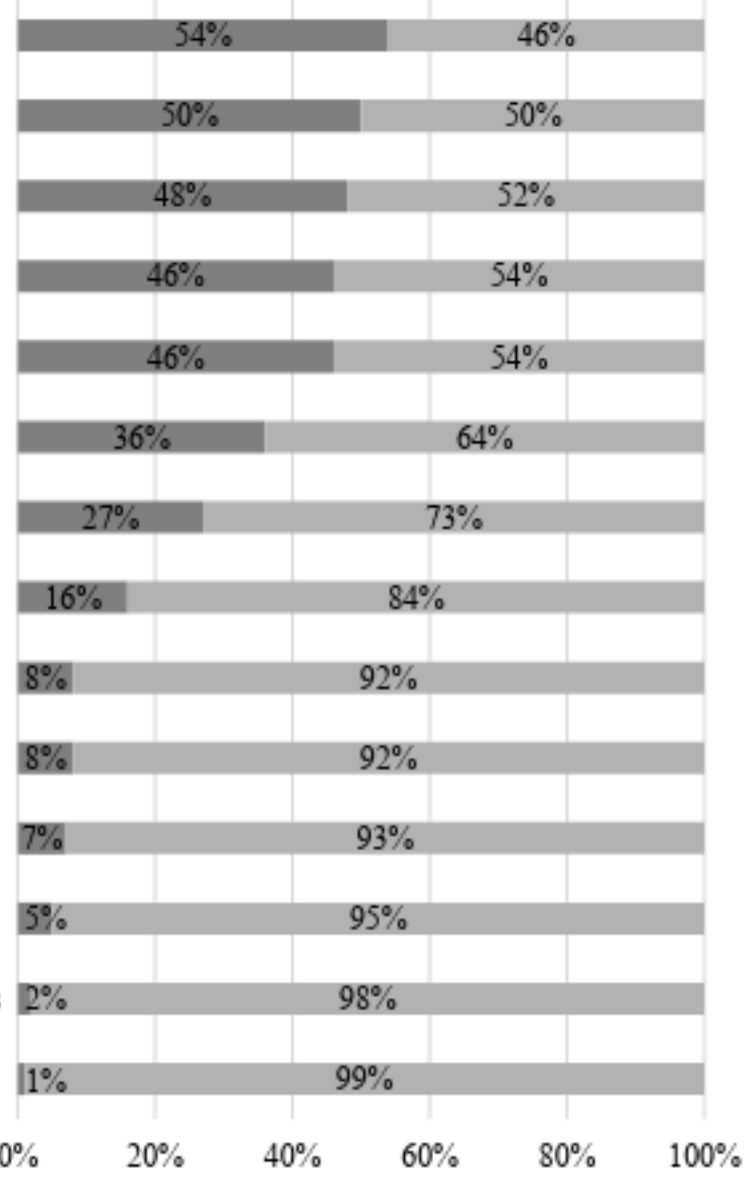

Yes No

Figure 2. Do program websites include sufficient diversity-related content critical for ethnic minorities to evaluate program climate concerns? 


\section{Appendix}

\section{Diversity and Inclusion Statement}

The Research, Educational Measurement, and Psychometrics (REMP) concentration at the University of Massachusetts is committed to increasing diversity and inclusiveness in our field. We provide equal opportunity to, and encourage applications from, people of all races, ethnicities, religions, genders, sexual orientations, gender identifications, incomes, ages, and physical abilities.

We acknowledge that diversity enhances the relevance and substance of our work. By embracing diversity and inclusion in all that we do, we strengthen our community, our pedagogy, our research, and the future design, development, and delivery of assessments that account for and value the inherent differences across and between diverse populations.

It is incumbent upon each member of the REMP community to share the responsibility of creating and maintaining an environment of mutual respect and support.

We recognize that diversity is an ongoing commitment, rather than an outcome measured in a single point in time. Consequently, REMP will continuously and proactively adhere to the following principles:

- Engagement: educate (through workshops, guest speakers, coursework, activities) our students and faculty to be social justice advocates

- Awareness: students and faculty must commit to, at all times, critically analyzing our own perspectives and identities, consider our implicit biases, and understand the impact these perspectives and biases have on the development of assessments

- Representativeness: actively work to increase the presence of underrepresented and historically marginalized groups in our program through intentional recruitment plans and comprehensive retention efforts

- Accountability: hold ourselves accountable for acknowledging and working against all forms of oppression and discrimination

The University's Diversity Strategic Plan can be found here 


\section{Supplementary Information}

\section{Diversity Project Variables}

Program characteristics

Flexibility for nontraditional students

Application information

Funding and job prospect opportunities

Program climate

\begin{tabular}{|c|c|c|c|c|c|c|}
\hline$\#$ & Code & Description & Data Source & Data Range & $\begin{array}{c}\% \\
\text { "Yes" }\end{array}$ & $\begin{array}{c}\text { Initial } \\
\text { Rater } \\
\text { Agreement }\end{array}$ \\
\hline 1 & Inst_Name & Institution name & NCME List 2017 & Text & N/A & $\mathrm{N} / \mathrm{A}$ \\
\hline 2 & Inst_State & Institution state & NCME List 2017 & Text & $\mathrm{N} / \mathrm{A}$ & $\mathrm{N} / \mathrm{A}$ \\
\hline 3 & Inst_City & Institution city & NCME List 2017 & Text & $\mathrm{N} / \mathrm{A}$ & $\mathrm{N} / \mathrm{A}$ \\
\hline 4 & Inst_Zip & Institution zip code & NCME List 2017 & 5-digit zip code & $\mathrm{N} / \mathrm{A}$ & $\mathrm{N} / \mathrm{A}$ \\
\hline 5 & P_Website & Program website & $\begin{array}{l}\text { NCME List } 2017 \\
\text { Program website }\end{array}$ & URL & N/A & N/A \\
\hline 6 & P_College & $\begin{array}{l}\text { Name of the college or school housing } \\
\text { the program }\end{array}$ & Program website & Text, $0=$ no & N/A & $95 \%$ \\
\hline 7 & P_Dept & $\begin{array}{c}\text { Name of the department housing the } \\
\text { program (use program name if there are } \\
\text { no departments at the college/school } \\
\text { level) }\end{array}$ & Program website & Text & $\mathrm{N} / \mathrm{A}$ & $100 \%$ \\
\hline 8 & P_Name & Program name & $\begin{array}{l}\text { NCME List } 2017 \\
\text { Program website }\end{array}$ & Text & N/A & $95 \%$ \\
\hline 9 & P_Area & $\begin{array}{l}\text { Measurement/psychometrics program } \\
\text { area (specialization, minor, emphasis, } \\
\text { specialty, etc.); if program itself is } \\
\text { broad and/or is housed in a program } \\
\text { with focus beyond psychometrics (i.e., } \\
\text { Dept. of Psychology, Psychology }\end{array}$ & Program website & Text, $0=$ no & $37 \%$ & $95 \%$ \\
\hline
\end{tabular}




\begin{tabular}{|c|c|c|c|c|c|c|}
\hline & & $\begin{array}{c}\text { Program), include area of specialization } \\
\text { beyond broad program name (this does } \\
\text { not refer to areas of research interest } \\
\text { within the measurement/psychometrics } \\
\text { program [e.g. measurement, program } \\
\text { evaluation, etc.]) }\end{array}$ & & & & \\
\hline 10 & P_PhD & $\begin{array}{c}\text { Does the program offer terminal PhD } \\
\text { degree? }\end{array}$ & Program website & $1=$ yes, $0=$ no & $86 \%$ & $100 \%$ \\
\hline 11 & P_EdD & $\begin{array}{c}\text { Does the program offer terminal EdD } \\
\text { degree? }\end{array}$ & Program website & $1=$ yes, $0=$ no & $2 \%$ & $100 \%$ \\
\hline 12 & P_EdS & $\begin{array}{l}\text { Does the program offer terminal } \\
\text { specialist degree? }\end{array}$ & Program website & $1=$ yes, $0=$ no & $4 \%$ & $100 \%$ \\
\hline 13 & P_Masters & $\begin{array}{c}\text { Does the program offer terminal } \\
\text { master's degree? }\end{array}$ & Program website & $1=$ yes, $0=$ no & $64 \%$ & $100 \%$ \\
\hline 14 & Career_Grads & $\begin{array}{l}\text { Is there information about the jobs } \\
\text { (roles, titles, companies, etc.) program } \\
\text { graduates have secured in the past? }\end{array}$ & Program website & $1=$ yes, $0=$ no & $64 \%$ & $86 \%$ \\
\hline 15 & Career_Info & $\begin{array}{l}\text { Is there a statement about } \\
\text { prospective/potential careers for } \\
\text { program graduates stated specifically as } \\
\text { the role they will occupy? (i.e., } \\
\text { statistician, psychometrician, } \\
\text { consultant, professor, etc.); statement } \\
\text { must be differentiated from that } \\
\text { describing the roles occupied by } \\
\text { program graduates (see "Career_Grads" } \\
\text { variable) }\end{array}$ & Program website & $1=$ yes, $0=$ no & $78 \%$ & $41 \%$ \\
\hline 16 & Career_Rates & $\begin{array}{l}\text { Is there quantitative information about } \\
\text { rates of employment for program } \\
\text { graduates? }\end{array}$ & Program website & $1=$ yes, $0=$ no & $3 \%$ & $100 \%$ \\
\hline 17 & Contact & $\begin{array}{l}\text { Is there an explicit statement suggesting } \\
\text { that students can and should contact the } \\
\text { program with any questions? (i.e., "If }\end{array}$ & Program website & $1=$ yes, $0=$ no & $52 \%$ & $68 \%$ \\
\hline
\end{tabular}




\begin{tabular}{|c|c|c|c|c|c|c|}
\hline & & $\begin{array}{c}\text { you have more specific questions..., } \\
\text { please feel free to contact...") }\end{array}$ & & & & \\
\hline 18 & Cost & $\begin{array}{l}\text { Is there a statement about expected } \\
\text { tuition costs (presented quantitatively)? }\end{array}$ & Program website & $1=$ yes, $0=$ no & $4 \%$ & $91 \%$ \\
\hline 19 & Disc_Stmt & $\begin{array}{l}\text { Is there an anti-discrimination or equal } \\
\text { opportunity statement that is either } \\
\text { program specific or reiterating the } \\
\text { general university policy at-large and } \\
\text { which refers (either generally to } \\
\text { practices of the program and/or) } \\
\text { specifically to the admissions process? }\end{array}$ & Program website & $1=$ yes, $0=$ no & $8 \%$ & $100 \%$ \\
\hline 20 & Distance $^{+}$ & $\begin{array}{c}\text { Is there a statement specifying that } \\
\text { students are able to complete this } \\
\text { program in full via a } \\
\text { remote/online/distance format? }\end{array}$ & Program website & $1=$ yes, $0^{+}=$no & $8 \%$ & $95 \%$ \\
\hline 21 & Evening $^{+}$ & $\begin{array}{l}\text { Is there a statement specifying that any } \\
\text { number of night classes are offered? }\end{array}$ & Program website & $1=$ yes, $0^{+}=$no & $11 \%$ & $100 \%$ \\
\hline 22 & PartTime $^{+}$ & $\begin{array}{l}\text { Is there an explicit statement specifying } \\
\text { that students can enroll on a part-time } \\
\text { basis? }\end{array}$ & Program website & $1=$ yes, $0^{+}=$no & $16 \%$ & $95 \%$ \\
\hline 23 & DivCourses_Gen* & $\begin{array}{l}\text { Are there mandatory courses (i.e. all } \\
\text { students in the program must complete) } \\
\text { on the topic(s) of general diversity? }\end{array}$ & Program website & $1=$ yes, $0=$ no & $8 \%$ & $95 \%$ \\
\hline 24 & DivCourses_Ethn $^{* *}$ & $\begin{array}{l}\text { Are there mandatory courses (i.e. all } \\
\text { students in the program must complete) } \\
\text { on the topic(s) of ethnic diversity? }\end{array}$ & Program website & $1=$ yes, $0=$ no & $1 \%$ & $95 \%$ \\
\hline 25 & DivStmt_Gen ${ }^{*}$ & $\begin{array}{l}\text { Is there an explicit statement related to } \\
\text { encouraging (i.e., welcoming and } \\
\text { accepting) general diversity among } \\
\text { program students (do not code for this } \\
\text { variable within "How to Apply" section } \\
\text { that provides instructions for writing } \\
\text { application statements)?" }\end{array}$ & Program website & $1=$ yes, $0=$ no & $16 \%$ & $95 \%$ \\
\hline
\end{tabular}




\begin{tabular}{|c|c|c|c|c|c|c|}
\hline 26 & DivStmt_Ethn ${ }^{* *}$ & $\begin{array}{l}\text { Is there a statement related to } \\
\text { encouraging (i.e., welcoming and } \\
\text { accepting) ethnic diversity among } \\
\text { program students (do not code for this } \\
\text { variable within "How to Apply" section } \\
\text { that provides instructions for writing } \\
\text { application statements)? }\end{array}$ & Program website & $1=$ yes, $0=$ no & $5 \%$ & $100 \%$ \\
\hline 27 & Fac_Images & $\begin{array}{l}\text { Is there at least one current faculty } \\
\text { member image (photo and/or video) } \\
\text { available on the program webpage or } \\
\text { through a link to an external faculty } \\
\text { directory? }\end{array}$ & Program website & $\begin{array}{c}1=\text { yes, } 0=\text { no, } \\
\text { Link=redirection } \\
\text { to external URL } \\
\text { (e.g., faculty } \\
\text { directory) }\end{array}$ & $54 \%$ & $95 \%$ \\
\hline 28 & Fac_Profiles & $\begin{array}{c}\text { Is there at least one faculty } \\
\text { profile/biography (including } \\
\text { information beyond simply their name } \\
\text { and job title) available on the program } \\
\text { webpage or through a link to an external } \\
\text { faculty directory? (i.e., statement(s) } \\
\text { related to research interests, previous } \\
\text { work, educational background, awards } \\
\text { and honors, etc.) }\end{array}$ & Program website & $\begin{array}{c}1=\text { yes, } 0=\text { no, } \\
\text { Link=redirection } \\
\text { to external URL } \\
\text { (e.g., faculty } \\
\text { directory) }\end{array}$ & $36 \%$ & $86 \%$ \\
\hline 29 & FacResearch_Gen ${ }^{*}$ & $\begin{array}{l}\text { When reviewing current faculty profiles } \\
\text { (via either program webpage or linked } \\
\text { to external faculty directory), is there } \\
\text { mention that at least one current faculty } \\
\text { member has research interest(s) related } \\
\text { to issues of general diversity? }\end{array}$ & Program website & $\begin{array}{c}1=\text { yes, } 0=\text { no, } \\
\text { N/A=no profile } \\
\text { available }\end{array}$ & $42 \%$ & $73 \%$ \\
\hline 30 & FacResearch_Ethn $^{* *}$ & $\begin{array}{l}\text { When reviewing current faculty profiles } \\
\text { (via either program webpage or linked } \\
\text { to external faculty directory), is there } \\
\text { mention that at least one current faculty } \\
\text { member has research interest(s) related } \\
\text { to issues of ethnic diversity? }\end{array}$ & Program website & $\begin{array}{c}1=\text { yes, } 0=\text { no, } \\
\text { N/A=no profile } \\
\text { available }\end{array}$ & $40 \%$ & $73 \%$ \\
\hline
\end{tabular}




\begin{tabular}{|c|c|c|c|c|c|c|}
\hline 31 & Flex_Review & $\begin{array}{l}\text { Is there an explicit statement related to } \\
\text { considerations provided or flexibility } \\
\text { applied during the admissions review } \\
\text { process for otherwise exceptional } \\
\text { applicants who might demonstrate } \\
\text { specific weaknesses in their application } \\
\text { materials (i.e., lower than average GRE } \\
\text { scores, lower than average GPA, lack of } \\
\text { research experience, etc.) }\end{array}$ & Program website & $1=$ yes, $0=$ no & $16 \%$ & $82 \%$ \\
\hline 32 & FundDiv_Gen* & $\begin{array}{l}\text { Is there information about the } \\
\text { availability of graduate student funding } \\
\text { (i.e., scholarships, assistantships, } \\
\text { fellowships, etc.) geared specifically } \\
\text { towards generally diverse students? }\end{array}$ & Program website & $1=$ yes, $0=$ no & $7 \%$ & $91 \%$ \\
\hline 33 & FundDiv_Ethn $^{* *}$ & $\begin{array}{l}\text { Is there information about the } \\
\text { availability of graduate student funding } \\
\text { (i.e., scholarships, assistantships, } \\
\text { fellowships, etc.) geared specifically } \\
\text { towards ethnically diverse students? }\end{array}$ & Program website & $1=$ yes, $0=$ no & $2 \%$ & $100 \%$ \\
\hline 34 & Fund_Info & $\begin{array}{l}\text { Is there any mention or information } \\
\text { about the availability of or possibility of } \\
\text { receiving graduate student funding (i.e., } \\
\text { scholarships, assistantships [teaching, } \\
\text { research, graduate], fellowships)? } \\
\text { Indicate if information is only available } \\
\text { via an external link to the institution's } \\
\text { financial services office without any } \\
\text { description on the program webpage } \\
\text { itself. }\end{array}$ & Program website & $\begin{array}{c}1=\text { yes, } 0=\text { no, } \\
\text { Link=redirection } \\
\text { to external URL } \\
\text { (e.g., financial } \\
\text { aid office) }\end{array}$ & $58 \%$ & $73 \%$ \\
\hline 35 & GRE_Emph & $\begin{array}{c}\text { Is there a statement emphasizing } \\
\text { importance or value of quantitative } \\
\text { GRE scores? }\end{array}$ & Program website & $1=$ yes, $0=$ no & $2 \%$ & $91 \%$ \\
\hline
\end{tabular}




\begin{tabular}{|c|c|c|c|c|c|c|}
\hline 36 & GRE_Suggest & $\begin{array}{l}\text { Is there quantitative mention of } \\
\text { expected/competitive GRE scores in } \\
\text { regards to the admissions process? }\end{array}$ & Program website & $1=$ yes, $0=$ no & $28 \%$ & $91 \%$ \\
\hline 37 & Handbook & $\begin{array}{l}\text { Is there a copy or a link to a program- } \\
\text { specific handbook? }\end{array}$ & Program website & $1=$ yes, $0=$ no & $32 \%$ & $91 \%$ \\
\hline 38 & Experience & $\begin{array}{l}\text { Is there information about past, current, } \\
\text { and/or future applied experience sites? } \\
\text { (i.e., internship, practicum, } \\
\text { apprenticeship, experiential learning, } \\
\text { etc.) }\end{array}$ & Program website & $1=$ yes, $0=$ no & $19 \%$ & $95 \%$ \\
\hline 39 & S_Contact & $\begin{array}{c}\text { Is past or current student contact } \\
\text { information available? (i.e. email } \\
\text { address, message/email portal, alumni } \\
\text { contact available through current } \\
\text { faculty, etc.) }\end{array}$ & Program website & $1=$ yes, $0=$ no & $27 \%$ & $100 \%$ \\
\hline 40 & S_Images & $\begin{array}{l}\text { Is there at least one past or current } \\
\text { student image (photo and/or video) } \\
\text { available? (If image is not specifically } \\
\text { attached to a student profile, the image } \\
\text { must minimally include a label } \\
\text { identifying the name(s) of the student(s) } \\
\text { in the photo and/or video.) }\end{array}$ & Program website & $1=$ yes, $0=$ no & $46 \%$ & $95 \%$ \\
\hline 41 & S_Profiles & $\begin{array}{l}\text { Is there at least one past or current } \\
\text { student profile/biography/statement that } \\
\text { includes information beyond student } \\
\text { name and program association, such as } \\
\text { their research interests, career plans, } \\
\text { accomplishments, awards, publications, } \\
\text { etc. (do not code alumni job placements } \\
\text { - see variable "Career_Grad")? }\end{array}$ & Program website & $1=$ yes, $0=$ no & $50 \%$ & $82 \%$ \\
\hline 42 & UG_GPA & $\begin{array}{l}\text { Is there a minimum undergraduate GPA } \\
\text { listed as a pre-requisite (if source of } \\
\text { GPA is not specified, code as "yes")? }\end{array}$ & Program website & $1=$ yes, $0=$ no & $32 \%$ & $91 \%$ \\
\hline
\end{tabular}




\begin{tabular}{|c|c|c|c|c|c|c|}
\hline 43 & Grad_GPA & $\begin{array}{l}\text { Is there a minimum graduate GPA listed } \\
\text { as a pre-requisite (for programs that } \\
\text { offer at least one degree beyond } \\
\text { master's level; if source of GPA is not } \\
\text { specified, do not code)? }\end{array}$ & Program website & $\begin{array}{c}1=\text { yes, } 0=\text { no, } \\
\text { N/A (if program } \\
\text { only offers } \\
\text { master's) }\end{array}$ & $12 \%$ & $\begin{array}{l}\text { Recoded } \\
\text { after } \\
\text { consensus }\end{array}$ \\
\hline 44 & Math & $\begin{array}{l}\text { Is a mathematics/statistics background } \\
\text { (either at the undergraduate or graduate } \\
\text { level) listed as a pre- } \\
\text { requisite/requirement (not simply being } \\
\text { preferred or encouraged)? }\end{array}$ & Program website & $1=$ yes, $0=$ no & $13 \%$ & $82 \%$ \\
\hline 45 & Inst_Setting & $\begin{array}{l}\text { What is the campus setting (rural, } \\
\text { urban, suburban, small)? }\end{array}$ & Peterson's database & Text & N/A & N/A \\
\hline 46 & Inst_Type & How is the institution funded? & Peterson's database & $\begin{array}{l}1=\text { public } \\
0=\text { private }\end{array}$ & N/A & $\mathrm{N} / \mathrm{A}$ \\
\hline 47 & Rent & $\begin{array}{c}\text { Average monthly rent for one-bedroom } \\
\text { apartment for institution zip code as of } \\
\text { December } 2017 \text {. }\end{array}$ & apartmentguide.com & Dollar amount & $\mathrm{N} / \mathrm{A}$ & $\mathrm{N} / \mathrm{A}$ \\
\hline 48 & MSI & $\begin{array}{l}\text { Is this a Minority Serving Institution } \\
\text { (AANAPISI - Asian American Native } \\
\text { American Pacific Islander Serving } \\
\text { Institutions; AANH - Alaska Native } \\
\text { Serving Institution; HBCU - } \\
\text { Historically Black Colleges \& } \\
\text { Universities; HSI - Hispanic Serving } \\
\text { Institutions; NASNTI - Native } \\
\text { American Serving Non-Tribal } \\
\text { Institutions; PBI - Predominantly Black } \\
\text { Institutions; TCU - Tribal Colleges \& } \\
\text { Universities) }\end{array}$ & MSI UPenn List & $\begin{array}{c}0=\text { no, } \\
\text { AANAPISI, } \\
\text { AANH, HBCU, } \\
\text { HSI, NASNTI, } \\
\text { PBI, TCU }\end{array}$ & $\mathrm{N} / \mathrm{A}$ & $\mathrm{N} / \mathrm{A}$ \\
\hline 49 & HSI & Is this a Hispanic Serving Institution? & MSI HACU List & $1=$ yes, $0=$ no & $\mathrm{N} / \mathrm{A}$ & $\mathrm{N} / \mathrm{A}$ \\
\hline 50 & NCME_List & $\begin{array}{l}\text { Is the program listed on NCME List } \\
2017 ?\end{array}$ & NCME List 2017 & $1=$ yes, $0=$ no & $\mathrm{N} / \mathrm{A}$ & $\mathrm{N} / \mathrm{A}$ \\
\hline
\end{tabular}




\begin{tabular}{|c|c|c|c|c|c|c|}
\hline 51 & APA_Div5_List & $\begin{array}{c}\text { Is the program listed on APA Division 5 } \\
\text { List 2017? }\end{array}$ & $\begin{array}{c}\text { APA Division 5 } \\
\text { List 2017 }\end{array}$ & 1=yes, 0=no & N/A & N/A \\
\hline
\end{tabular}

Note. " "General Diversity" was defined as any non-specific ways of emphasizing differences among groups of individuals through the use of terms such as "multi-, inter-, and cross-culturalism" or referring to non-specific "diverse," "minority," "underrepresented," "marginalized," or "underserved" groups of individuals (do not review/code statements pertaining to international, linguistic, or religious diversity, disability, gender inequality/parity/feminism/sexism, etc.).

** "Ethnic Diversity" was defined as ways of emphasizing domestic ethnic or racial differences among groups of individuals by referring to individual ethnic or racial categories or using terms such as "race," "ethnicity," or "racism."

+ Code of "0" ("no") refers both to when no information was found or when the information was found, but it indicated that the variable of interest is not an option/is unavailable.

The rater agreement provided is based on initial ratings. Upon calculating rater agreement, variables with disagreement were resolved via consensus between the two raters. Furthermore, where needed, the principal investigators provided clarification for resolving disagreements. 


\section{Additional Exclusion \& Inclusion Rules for Reviewing and Coding}

1. In general, review/code only program's unique webpages, not external (department, institution, etc.) pages or links (e.g., links to financial aid office webpage) or margins that are common to the entire domain.

2. Review documents or forms linked through the program webpage (e.g., PDFs of course or program of study, GA applications, etc.), except for program handbooks and similar comprehensive program documents (e.g. "Governance \& Operating Procedures"), application forms, or documents and forms that are not unique to the program being reviewed (i.e. forms that students from other programs use as well).

3. Review/code videos if they are specific to the program (student interviews, faculty introductions, promotional videos, etc.), even if the video is hosted on a different platform (e.g. youtube)

4. If reviewing a specialization/area within a more general program (e.g. Psychology), review/code more general information that is generic to all specializations/areas and information unique to the psychometrics/measurement training, but do not review/code webpages unique to other specializations.

5. Do not review/code at the department level, unless there is only one program within the department (PhD in Psychology or $\mathrm{PhD}$ in Education); if that one program under the department has different specializations/areas, treat the department as the program and specific focus on psychometrics as area (see "P_Area" for specific description).

6. Do not review/code: blog archives; program newsletters, booklets, or news feeds; audio podcasts; institution catalog entries for the program; course syllabi; stand-alone documents pertaining specifically to comprehensive examination, dissertation preparation, study materials, student evaluation portfolios, etc.; pages, sections, or documents pertaining specifically to international students; pages, sections, or documents pertaining specifically to graduate certificates in psychometrics, undergraduate and/or fifth year programs, or minors/cognates for students from other programs.

7. For faculty profiles:

a. Do not review/code links for affiliated or emeritus faculty.

b. Review/code for faculty photos and diverse research interests even if profiles are only available through a link to external faculty directory (excluding faculty's personal websites or attached/displayed curriculum vitae); the link to faculty profile page has to be located on the program webpage, not in the margins that are common to the entire domain.

c. When reviewing faculty profiles for programs where psychometrics/measurement training is provided through a specialization and faculty associated with the psychometrics/measurement program is not clearly identified, only review the profiles of those whose names appear on the program-specific pages or are otherwise clearly labeled as being affiliated with this program (e.g. program name after their title, etc.)

8. If the program offers several degrees (e.g. $\mathrm{PhD}$ and Master's), code items even if it only appears in one (e.g. if there is a diversity course that is mandatory for PhD students, but not for Master's students, code DivCourses_... variable/s as “yes"); if there is conflicting information between several degrees, code with the bias for desired variable outcome (e.g. if the program 
utilizes a flexible review of application during admissions for Master's students, but not for PhD students and for PhD students every item on the application is listed as important, code as "yes"; if part-time is an option for Master's students, but discouraged for PhD students, code as "yes"; if PhD students are almost always funded, but that doesn't apply to Master's students, code as "yes"). 